\title{
Keanekaragaman Makrofauna Tanah Di Zona Rehabilitasi Taman Nasional Gunung Ciremai Blok Pasirbatang Desa Karangsari Kabupaten Kuningan
}

\author{
Ika Karyaningsih ${ }^{1}$, Yayan Hendrayana ${ }^{2}$, Iwan Kustiawan ${ }^{3}$ \\ ${ }^{123}$ Fakultas Kehutanan Universitas Kuningan \\ E-mail : ika_karyaningsih@uniku.ac.id
}

\begin{abstract}
APA Citation: Karyaningsih, I., Hendrayana, Y., \& Kustiawan, I. (2021). Keanekaragaman Makrofauna Tanah Di Zona Rehabilitasi Taman Nasional Gunung Ciremai Blok Pasir Batang Desa Karangsari Kabupaten Kuningan. Quagga: Jurnal Pendidikan dan Biologi, 13(1), 60-67. doi: 10.25134/quagga.v13i1.3521.
\end{abstract}

Received: $30-09-2020$

Accepted: 07-12-2020

Published: 01-01-2021

\begin{abstract}
Abstrak: Blok Pasirbatang adalah wilayah taman nasional gunung ciremai yang aktif untuk direklamasi disamping juga digunakan untuk wisata bumi perkemahan. Keberadaan organisme penghuni tanah berperan sangat besar dalam perbaikan kesuburan tanah tetapi juga menjadi ancaman bagi para pengunjung. Penelitian ini bertujuan mengetahui keanekaragaman makrofauna tanah. Tanah di wilayah buper pasir batang adalah tanah latosol coklat-hingga coklat kemerahan dengan rerata pH normal 6, KTK tinggi, suhu udara mencapai 18-23, sedangkan suhu tanah dapat mencapai 17 C. Makrofauna yang terdapat di Buper Pasir Batang terdiri dari 1 filum arthropoda dengan 10 ordo dan 13 famili. INP terbesar adalah rayap walaupun yang didapati adalah larva dengan jumlah individu larva mencapai 305. Peran makrofauna di dominasi oleh detrivore dan juga ada jenis fauna tanah yang harus diwaspadai sebagai predator. Keanekaragaman makrofauna termasuk dalam kategori sedang dengan distribusi yang relatif merata pada semua lokasi dengan nilai $C<1$. Untuk rehabilitasi/penanaman perlu adanya input bahan onganik tambahan untuk meningkatkan kolonisasi makrofauna tanah sehingga akan dapat meningkatkan peran makrofauna tanah dalam mineralisasi bahan organik. Jenis Makrofauna tanah sebagai predator perlu diwaspadai agar tidak melukai pengunjung buper.
\end{abstract}

Kata kunci: Tanah, makrofauna tanah, zona rehabilitasi

Abstract: Pasirbatang Block is an area of mount ciremai national park that is active to be reclaimed in addition to also used for campground tours. The existence of soil-dwelling organisms plays a huge role in the improvement of soil fertility but also becomes a threat to visitors. This research aims to find outthevarious uniformity of soil macrophauna. Soil in the buper area of sand rods is brown-to-brown latosolsoil with a normal pH average of 6, high KTK, air temperature reaches 18-23, while the soil temperature can reach 17 C. Macrophauna found in Buper Pasir Batang consist of 1 arthropod phylum with 10 order and 13 families. The largest INP is termites although what is found is the larvae with an individual number of larvae reaching 305. The role of macrophauna is dominated by detrivores and there are also types of soil fauna that must be alerted as predators. Macrophauna diversity belongs to a medium category with a relatively even distribution of all locations with a value of $C<1$. For rehabilitation / planting there needs to be additional onganic material inputs to increase colonization of soil macrophauna so that it will be ableto increase the role of soil macrophauna in mineralization of organi materialk. Types of soil macrophauna as predators need to be vigilant so as not to injure visitors buper.

Keywords: Soil, soil macrophauna, rehabilitation zone

\section{PENDAHULUAN}

Fauna tanah merupakan salah satu komponen tanah. Menurut Setiadi (1998) serangga berperan penting di dalam ekosistemnya sebagai perombak bahan organik yang tersedia bagi tumbuhan hijau. Nutrisi tanaman yang berasal dari berbagai residu tanaman akan mengalami proses perombakan sehingga berbentuk humus sebagai sumber nutrisi bagi tanah. Serangga tanah memainkan peranan yang sangat penting dalam pembusukan zat atau bahan-bahan organik. Fauna tanah merupakan pemakan bahan organik yang membusuk membantu merubah zat-zat organik menjadi zat yang lebih sederhana yang dikembalikan ke tanah, mereka juga bertindak menyingkirkan zat-zat yang tidak sehat dan berbahaya dari lingkungan (Borror et al., 1992). Peranan tersebut tidak dapat dirasakan langsung oleh manusia tetapi dapat dimanfaatkan setelah melalui jasa biota lainnya. Oleh karena itu, peranan utamanya di dalam ekosistem menjadi 
kurang mendapat perhatian. Padahal tanpa kehadiran fauna tanah maka perombakan tumpukan bahan organik di lingkungan berjalan sangat lambat. Sehingga sangatlah penting keberadaan dan peran fauna tanah terutama untuk memperbaiki kondisi tanah sebagai tempat tumbuh tumbuhan, yang selanjutnya akan peningkatkan pertumbuhan tanaman dalam upaya perbaikan kondisi ekologi suatu wilayah.

Kehidupan fauna tanah sangat tergantung pada habitatnya, karena keberadaan dan kepadatan populasi suatu jenis fauna tanah di suatu daerah sangat ditentukan oleh keadaan daerah tersebut. Dengan perkataan lain keberadaan dan kepadatan populasi suatu jenis fauna tanah di suatu daerah sangat tergantung dari faktor lingkungan, yaitu lingkungan biotik dan lingkungan abiotik. Fauna tanah merupakan bagian dari ekosistem tanah, oleh karena itu dalam mempelajari ekologi fauna tanah maka faktor fisika-kimia tanah selalu diukur (Suin, 1991). Wilayah zona rehabilitasi tanaman nasional gunung ciremai blok pasir batang desa karangsari merupakan wilayah bekas tambang pasir pada masa lalu yang hingga saat ini masih membutuhkan rehabilitasi yang menyeluruh, oleh sebab itu untuk mendapatkan pengelolaan yang tepat di wilayah ini diperlukan informasi tentang kondisi tanah baik biotik meliputi makrofauna tanah dan abiotiknya terutama sifat fisik dan kimia tanah.

Wialayah Blok Pasirbatang ini pula digunakan sebagai tempat wisata Bumi Perkemahan yang sangat aktif. Hampir setiap hari banyak pengunjung datang ke Buper ini baik masyarakat sekitar kuningan maupun di luar kota kuningan. Di akhir minggu banyak masyarakat yang bertenda atau berkunjung menikmati suasana pegunungan, apalagi dimasa liburan jumlah pengunjung akan semakin banyak. Keamanan pengunjung ini perlu untuk diperhatikan baik dari binatang besar maupun binatang kecil termasuk fauna tanah ini. Keberadaan fauna tanah di pasirbatang perlu diketahui baik jenis, fungsi dan potensinya terutama untuk keamanan pengunjung. Maka keberadaan fauna tanah selain memberikan dampak positif bagi lingkungan juga perlu untuk diwaspadai keberadaannya akan mengganggu pengunjung bumi perkemahan. Tujuan penelitian ini adalah keanekaragaman makrofauna tanah dan fungsinya di Blok Pasirbatang Taman Nasional Gunung Ciremai. Oleh sebab itu perlu untuk diketahui keanekaragaman jenis makrofauna tanah.

\section{METODOLOGI PENELITIAN}

\section{Pengambilan data}

Tempat penelitian adalah di wilayah zona rehabilitasi Taman Nasional Gunung Ciremai Blok Pasirbatang Desa Karangsari Kecamatan Darma Kabupaten Kuningan. Pengamatan dilakukan dengan membuat jalur sepanjang 1 $\mathrm{km}$ melintasi bumi perkemahan, kemudian dibuat plot berukuran $5 \times 2 \mathrm{~m}$ dengan jarak antar plot $95 \mathrm{~m}$ sehingga terdapat 10 plot contoh. Setiap plot dibuat 4 subplot yang bertindak juga sebagai ulangan. Petak sub plot dibuat dengan ukuran $30 \mathrm{~cm} \times 30 \mathrm{~cm} \times 15 \mathrm{~cm}$. Lapisan tanah setebal $15 \mathrm{~cm}$ pada sub plot juga dipindahkan kedalam trashbag bening yang lain secara cepat. Seluruh makrofauna tanah yang berada di serasah dan di dalam tanah selanjutnya dikumpulkan secara handsorting method (pengumpulan menggunkan tangan) yang dibantu dengan pinset. Hewan tanah yang terambil dimasukkan dalam tabung plastik berisi alkohol $70 \%$. Hewan yang telah dimasukkan kedalam alkohol $70 \%$ selanjutnya difoto dan dideskripsikan dan diidentifikasi.

Seluruh maskrofauna tanah yang tertangkap dari serasah dan bahan tanah diidentifikasi diusahakan sampai tingkaf famili menggunakan beberapa buku seperti Pengenalan Pelajaran Serangga (Borror et al., 1996) dan sumber-sumber lain. Identifikasi ini akan dilaksanakan di Laboraturium Silvikultur Fakultas Kehutanan Universitas Kuningan.

Pada setiap titik sampling makrofauna tanah juga dilakukan pengukuran beberapa variabel faktor lingkungan, yaitu: penetrasi cahaya, kelembaban udara, suhu udara, suhu tanah, kelembaban tanah, $\mathrm{pH}$ tanah, produksi serasah sengon dan keragaman vegetasi bawah. Pengukuran variabel faktor lingkungan dilakukan pada siang hari antara pukul 12.00 sampai dengan 14.00 . 


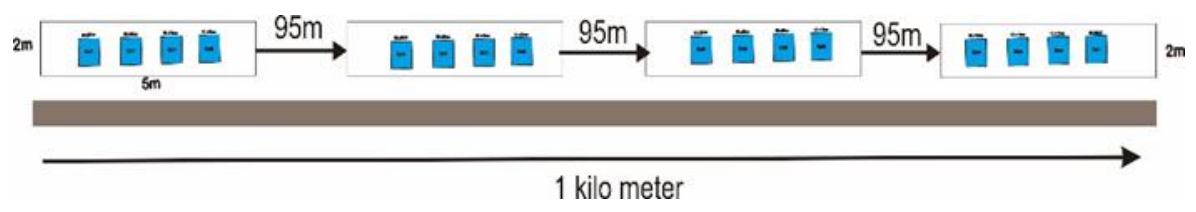

\section{Analisis Data}

Analisis tanah yang dilakukan antara lain sifat tanah fisik meliputi struktur tanah, tekstur tanah, suhu, kelembaban, porositas. Sedangkan sifat kimia tanah meliputi $\mathrm{pH}, \mathrm{C} / \mathrm{N}$ rasio, KTK tanah. Pada makrofauna tanah dihitung untuk mengetahui nilai penting spesies yang ditemukan yaitu indeks nilai pentingnya berdasarkan kepadatan relatif dan frekuensi relatifnya, selanjutnya Index keanekaragaman shanon-wiener (H'), Indeks kemerataan (E), dan Indeks kekayaan (Dmg),

a. Index keanekaragaman shanon-wiener (diversity indeks)

(Ludwig and Reynolds, 1988) $\mathrm{H}^{`}=-\sum \mathrm{pi} \ln \mathrm{pi}$

Keterangan :

$\mathrm{H}^{\prime}=$ indeks keanekaragaman shanonwiener

$\mathrm{pi}=\mathrm{ni} / \mathrm{N}$

$\mathrm{ni}=$ jumlah individu jenis ke $\mathrm{i}$

$\mathrm{N}=$ jumlah individu seluruh jenis

Kriteria :

$\mathrm{H}^{\prime}<1,5 \quad$ : $\quad$ keanekaragaman

rendah

H' $1.5-3,5$ : keanekaragaman

sedang

$\mathrm{H}^{\prime}>1,5 \quad: \quad$ keanekaragaman tinggi

b. Indeks kemerataan (eveness) (Ludwig and Reynolds, 1988)

$$
\mathrm{E}=\mathrm{H}^{\prime} / \ln \mathrm{S}
$$

Keterangan :

$\mathrm{E}=$ indeks kemerataan (eveness)

$\mathrm{S}=$ jumlah spesies $(\mathrm{n} 1, \mathrm{n} 2, \mathrm{n} 3, \ldots \ldots \ldots)$

Kriteria :

$$
\begin{aligned}
& \text { E }<0,3 \quad: \text { kemerataan rendah } \\
& \text { E } 0,3-0,6 \quad: \text { kemerataan sedang } \\
& \text { E }>0,6: \text { kemerataan tinggi }
\end{aligned}
$$

c. Indeks kekayaan (richness)

Dmg $=\mathrm{S}-1 / \mathrm{ln} \mathrm{N}$

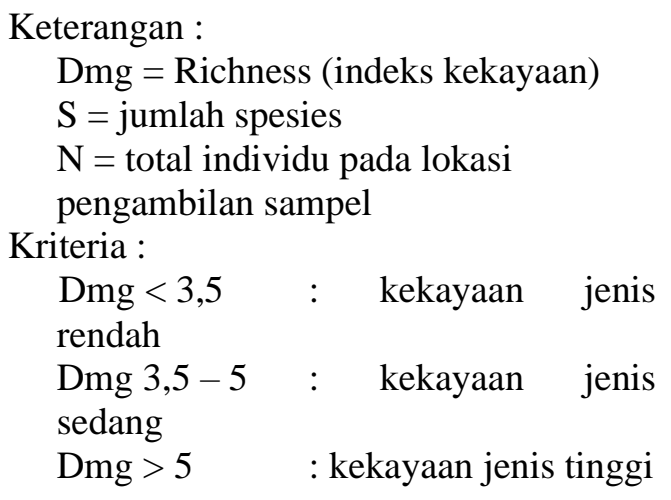

\section{HASIL DAN PEMBAHASAN
a. Biodiversitas dan Peran Makrofauna Tanah

Kelimpahan dan komposisi makrofauna dari wilayah buper pasir batang desa karangsari terdiri dari 10 ordo, 13 famili dan 411 individu, ditemukan dalam bentuk individu dewasa maupun dalam bentuk larva. Kelimpahan makrofauna rayap ditemukan dalam jumlah terbesar, berada tepat dibawah permukaan serasah. Kelimpahan makrofauna tanah diduga dipengaruhi oleh kondisi lingkungan sehingga faktor lingkungan tanah perlu diperhatikan. Perubahan pada lingkungan akan berdampak pada keberadaan makrofauna tanah baik secara langsung maupun tidak langsung. Keberadaan daun pinus yang relatif sulit terurai menyebabkan tertumpuknya serasah pinus sehingga kondisi lingkungan relatif lebih lembab dan mendorong kolonisasi makrofauna yang berfungsi sebagai dekomposer lebih banyak dari pada makrofauna jenis yang lain. Tingginya kelimpahan makrofauna tanah pada tegakan pinus yang memiliki tegakan yang rapat juga karena tegakan yang rapat meyebabkan sinar matahari yang masuk dalam tegakan lebih sedikit dan tanah lebih lembab. Kualitas dan kuantitas makanan yang cukup akan meningkatkan jumlah individu makrofauna di dalam tanah. 


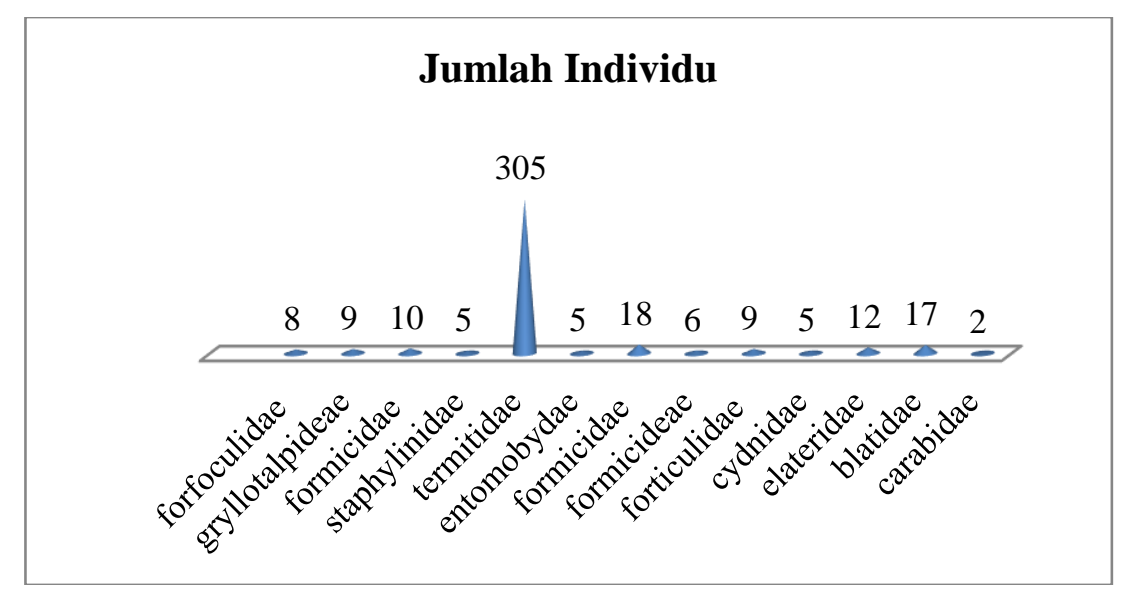

Gambar1. Jumlah individu yang ditemukan

Berbagai jenis organisme tanah yang umumnya termasuk anggota invertebrata telah banyak dilaporkan memegang peranan penting dalam proses-proses penting dalam ekosistem terutama di daerah tropis (Lavelle et. al 1994). Dijelaskan bahwa makrofauna tanah (fauna $>2 \mathrm{~mm}$ ) merupakan bagian dari biodiversitas tanah yang berperan penting dalam perbaikan sifat fisik, kimia dan biologi tanah melalui proses immobilisasi dan
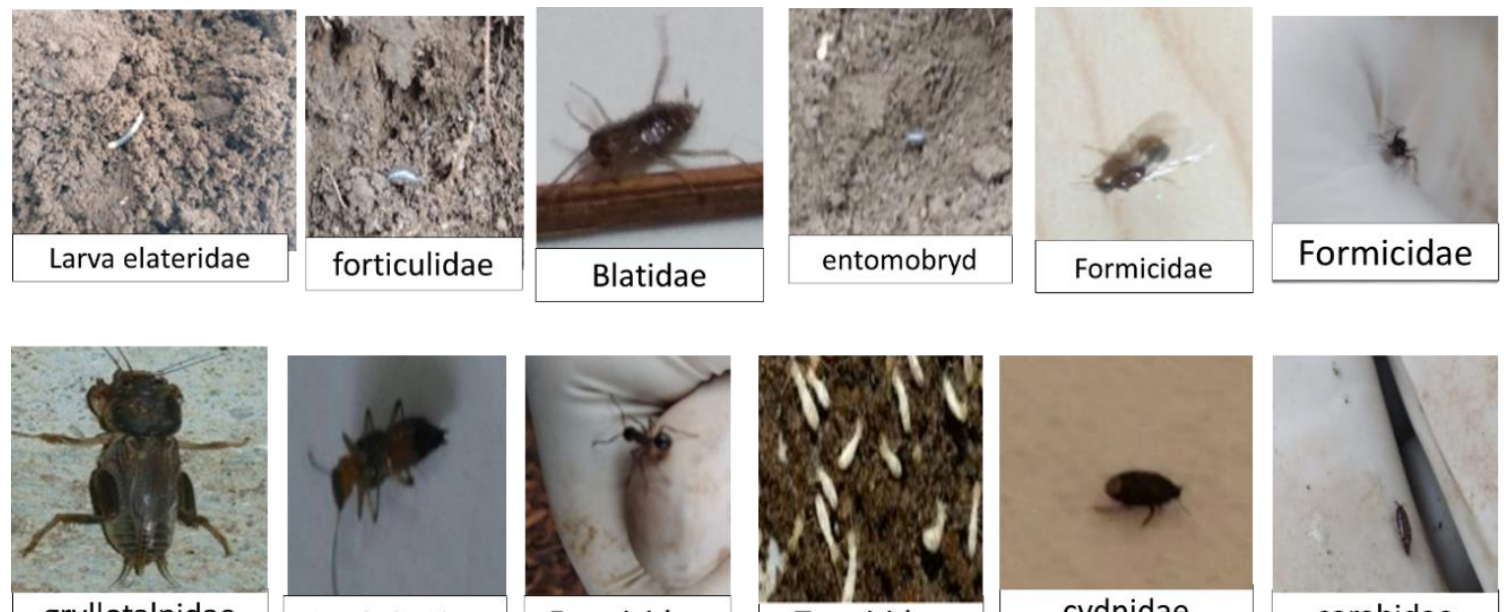

gryllotalpidae
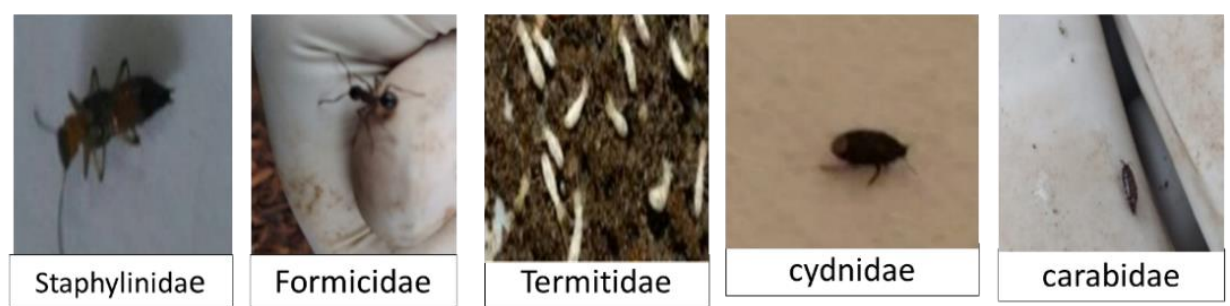

Gambar 2. Jenis Fakrofauna yang ditemukan

Hasil perhitungan nilai indeks diversitas yang disajikan dalam tabel 1 mununjukan bahwa keanekaragaman makrofauna pada tegakan pinus di buper pasir batang desa karangsari adalah (H') 1,176 dengan kategori rendah; nilai kekayaan jenis (DMg) sebesar 1,994 juga menunjukkan kategori rendah, nilai kemerataan/eveness (E) sebesar 1.99 termasuk kategori sedang dan nilai $\mathrm{C}$ sebesar 0,55 yang menunjukkan makrofauna penyebarannya cukup merata. Menurut Sembel (2010) keanekaragaman fauna tanah dipengaruhi oleh variasi makanan yang tersedia di lingkungan. Menurut Wibowo (2014) Keanekaragaman makrofauna pada tanaman agathis lebih besar daripada makrofauna yang terdapat pada tegakan pinus. Hal ini diduga karena jumlah serasah yang berada pada tegakan pinus lebih sedikit dan lebih jarang ditemukan tumbuhan bawah disekitar tegakan sehingga ketersediaan 
bahan makanan untuk makrofauna menjadi lebih sedikit.

Tabel 1. Nilai Biodiversitas makrofauna tanah pada tegakan pinus

\begin{tabular}{ccc}
\hline Keterangan & Nilai & Kategori \\
\hline H' & 1,176 & Rendah \\
DMg & 1,994 & Rendah \\
E & 1,99 & Sedang \\
C & 0,55 & merata \\
\hline
\end{tabular}

\section{Meningkatnya keanekaragaman} makrofauna di dalam tanah dengan meningkatnyan kandungan bahan organik tanah dan dominasi vegetasi bawah disebabkan oleh karena bahan organik tanah maupun sisasisa tenaman dari vegetasi bawah dapat dimanfaatkan oleh makrofauna didalam tanah sebagai bahan makanannya. Semakin banyak tersedia bahan makanan maka semakin beragam pula makrofauna yang dapat eksis di habitat tersebut. Disamping itu, keberadaan bahan organik tanah dan vegetasi bawah dapat memberikan kondisi mikrohabitat lebih baik untuk menunjang kehidupan berbagai jenis organisme tanah ternasuk makrofauna di dalamnya. Keanekaragaman yang telah dianalisis pada penelitian ini adalah nilai kekayaan jenis $(\mathrm{DMg})$, nilai keanekaragaman (H'), Kemerataan (E) dan C. Kekayaan spesies (richness) makrofauna tanah mengacu pada banyaknya spesies yang ditemukan pada suatu ekosistem. Jumlah total spesies dalam suatu komunitas tergantung pada ukuran sampel dan waktu.

Setiap makrofauna tanah memiliki peran dan fungsi yang berbeda-beda sehingga dalam daur hidupnya kan memperbaiki kondisi tanah dan lingkungan yang ada di sekitarnya. Peran makrofauna tanha yang ditemukan di lokasi penelitian seperti ditunjukan pada tabel 2 . Makrofauna yang berperan sebagai herbifora terdapat 4 famili yaitu: Gryllotalpideae, Stephylinideae, Cydnidae, dan Elateridae. Makrofauna yang berperan sebagai predator terdapat 3 ordo dan 3 famili atau suku yaitu: Formicidae, Forticulidae dan Carabidae. Sedangkan 3 famili bertindak sebgai dekomposer yaitu: Termitidae, Entomobydae dan Blatidae. Jumlah individu terbanyak makrofauna tanah berperan sebagai dekomposer. Peran makrofauna tanah berdasar jumlah famili dan jumlah individu dapat dilihat pada tabel 1 .

Tabel 2. Peran makrofauna tanah buper pasir batang desa karangsari

\begin{tabular}{cccc}
\hline No. & Ordo & Famili & Peran \\
\hline 1. & dermaptera & forfoculidae & Predator \\
2. & orthoptera & gryllotalpideae & herbivora \\
3. & hymeneoptera & formicidae & predator \\
4. & coleoptera & staphylinidae & herbivora \\
5. & blattodea & termitidae & dekomposer \\
6. & colembola & entomobydae & dekomposer \\
7. & hymeneoptera & formicidae & predator \\
8. & hymeneoptera & formicideae & predator \\
9. & dermaptera & forticulidae & predator \\
10. & hemiptera & cydnidae & herbivora \\
11. & coleoptera & elateridae & herbivora \\
12. & blattodea & blatidae & dekomposer \\
13. & gleoptera & carabidae & predator \\
\hline
\end{tabular}


Frekuensi adalah menunjukan seringnya makrofauna tanah yang ditemukan di plot penelitian. Data frekuensi makrofauna dengan nilai frekuensi relatif tertinggi adalah pada famili termitidae. Kerapatan menunjukakan besarnya jumlah individu pada plot penelitian. Data kerapatan terbesar adalah pada famili termitidae sebesar 0,742. Berdasar nilai kerapatan relatif dan frekuensi relatif ini sehingga nilai indeks nilai penting makrofauna tanah tertinggi adalah famili termitidae sebesar 0,854 ditemukan dalam bentuk larva dan rayap tanah dewasa.

Penelitian Sugiyarto (2000) menunjukan bahwa keanekaragaman makrofauna permukaan tanah lebih tinggi dibanding makrofauna di dalam tanah. Tingginya keanekaragaman makrofauna permukaan tanah disebabkan oleh lebih tersedianya berbagai bahan organik tanaman yang berasal dari tegakan pinus maupun vegetasi bawahnya. Dan keberadaan makrofauna di permukaan tanah mungkin bersifat sementara, temporal dan periodik. Sedangkan di dalam tanah kemungkinan kebanyakan makrofauna bersifat permanen.

Pengamatan yang dilakukan menunjukkan adanya makrofauna yang berperan sebagai predator, hal ini perlu diwaspadai terutama untuk para pengunjung buper Pasirbatang.sanya Fauna predator biasanya mengandung racun di dalam tubuhnya yang berfungsi melumpuhkan musuhmusuhnya. Racun ini berpotensi memberikan rasa tidak nyaman pada pengunjung dari tingkat terendah hanya berupa gatal kemerahan hingga rasa keracunan yang dapat menyebabkan kematian. Seperti tomcat adalah serangga berbahaya dengan tubuh berukuran seperti nyamuk ini memiliki warna belang kuning dan hitam pada tubuhnya. Serangga ini menjadi populer di masyarakat karena gigitannya yang bisa bikin iritasi di kulit, menimbulkan_rasa terbakar selama beberapa jam, serta kemerahan pada kulit dan bahkan menyebabkan lepuhanlepuhan kulit berisi nanah jika terkena gigitannya.

Tomcat biasanya muncul dengan gerakan merayap. Mengapa demikian? Karena hewan ini menyembunyikan sayapnya ketika berjalan merayap dan akhirnya terlihat lebih seperti semut. Jika terganggu maka akan meningkatkan porsi racun di perut tomcat seperti kalajengking. Tomcat melakukan hal tersebut guna menakut-nakuti musuh. Cairan tersebut adalah cairan hemolim atau racun "aederin". Tomcat secara otomatis akan melepaskan cairan racun ketika terkena kontak atau bertabrakan dengan kulit manusia. Tomcat juga akan mengeluarkan cairan racun tersebut pada benda-benda seperti pakaian, handuk, atau benda lainnya. Nah, jika terkena seprei, handuk dan peralatan yang diduga terkena racun tomcat harus segera dicuci.

\section{b. Hubungan Faktor Lingkungan dengan Keanekaragaman Makrofauna di Tanah Hutan Buper Pasir Barang Desa Karangsari}

Analisis Abiotik tanah wilayah bumi perkemahan Pasir Batang Desa karangsari adalah Kondisi ketebalan serasah dibawah tegakan pinus sebesar 5,2 cm dengan $\mathrm{pH}$ tanah mendekati nornal sebesar 5,8 hal ini masih dalam ambang pertumbuhan makrofauna walaupun agak lebih bersifat asam. Kelembaban tanah mencapai $68,87 \%$. temperatur tanah sebesar $17{ }^{\circ} \mathrm{C}$ dan temperatur udara mencapai $17,5^{\circ} \mathrm{C}$. Jenis tanah termasuk latosol coklat hingga latosol coklat kemerahan, KTK relatif tinggi dengan C-organik sebesar 5 yang termasuk kategori sedang.

Tabel 3. Analisis abiotik tanah buper Pasir Batang desa Karangsari

\begin{tabular}{ll}
\hline Parameter & Nilai \\
\hline Ketebalan serasah & $5,2(\mathrm{~cm})$ \\
pH tanah & 5,8 \\
Kelembaban tanah & $68,87 \%$ \\
Temperatur tanah & $17,5 \mathrm{C}$ \\
Temperatir udara & 19 \\
Jenis tanah & Latosol coklat-latosol coklat kemerahan \\
KTK & Tinggi \\
C- organik & 5 (sedang) \\
\hline
\end{tabular}


Fauna tanah memerlukan persyaratan tertentu untuk menjamin kelangsungan hidupnya. Struktur dan komposisi makrofauna tanah sangat tergantung pada kondisi lingkungannya. Makrofauna tanah lebih menyukai keadaan lembab dan masam lemah sampai netral (Notohadiprawiro, 1998). Makalew (2001) menjelaskan faktor lingkungan yang dapat mempengaruhi aktifitas organisme tanah yaitu: iklim (curah hujan dan suhu), tanah (keasaman, kelembaban, suhu tanah, hara) dan vegetasi (hutan, padang rumput), serta cahaya matahari. Kehidupan organisme tidak sendiri, tetapi berinteraksi dengan faktor lainnya. Seperti faktor fisika dan faktor kimia dari lingkungan tempatnya hidup. Adanya interaksi sangat menentukan penyebaran dan kepadatan hewan tersebut (Suin, 2003). Makrofauna tanah akan melimpah pada habitat yang mampu menyediakan faktor-faktor yang dapat mendukung kehidupan makrofauna tanah seperti ketersediaan makanan, suhu yang optimal dan ada atau tidaknya predator/musuh. Suhu tanah merupakan salah satu faktor fisika tanah yang sangat menentukan kehadiran dan kepadatan organisme tanah, sehingga suhu tanah akan menentukan tingkat dekomposisi material organik tanah. Suhu tanah yang terdapat dalam plot pengamatan berkisar 17-20 ${ }^{0} \mathrm{C}$, kondisi ini memungkinkan untuk pertumbuhan makrofauna secara optimal. Bahan organik tanaman merupakan sumber energi utama bagi kehidupan biota tanah, khususnya makrofauna tanah (Suin, 2003) sehingga jenis dan komposisi bahan organik tanaman menentukan kepadatannya. Menurut Priyadarshini (1999) bahan organik tanman akan mempengaruhi tata udara di dalam tanah dengan adanya pori tanah karena adanya aktifitas biota tanah.

\section{SIMPULAN}

Tanah di wilayah buper pasir batang adalah tanah latosol coklat-hingga coklat kemerahan dengan rerata $\mathrm{pH}$ normal 6 , KTK tinggi, suhu udara mencapai 18-23, sedangkan suhu tanah dapat mencapai $17{ }^{\circ} \mathrm{C}$.

Makrofauna yang terdapat di buper pasir batang terdiri dari 1 filum arthropoda dengan 10 ordo dan 13 famili. INP terbesar adalah rayap walaupun yang didapati adalah larva dengan jumlah individu larva mencapai 305. Peran makrofauna di dominasi oleh detrivore walaupun ada jenis yang harus diwaspadai sebagai predator. Keanekaragaman makrofauna termasuk dalam kategori sedang dengan distribusi yang relatif merata pada semua lokasi.

\section{UCAPAN TERIMA KASIH}

Kami ucapkan terima kasih kepada Universitas Kuningan atas dukungan pendanaan penelitian, Pengelola Buper Pasirbatang Desa Karangsari dan Civitas Akademika Fakultas Kehutanan Universitas Kuningan.

\section{REFERENSI}

Borror D.J, Charles A.T, and Norman F.J. 1996. Pengenalan Pelajaran Serangga. Partosoedjono S, penerjemah. Yogyakarta: Gadjah Mada University Press. Terjemahan dari: An Introduction to the Study of Insect.

Lavelle, P., et.al. 1994. The relationship between soil macrofauna and tropical soil fertility. In Woomer, P.L. Swift (eds) the botanical manageman of tropical soil fertility. Chichester: John wiley $\&$ son.

Makalew, A.D.N. 2001. Keanekaragaman Biota Tanah Pada Agroekosistem Tanpa Olah Tanah (TOT). Makalah Falsafah Sains. Program Pasca Sarjana/S3.

Notohadiprawiro, T. 1998. Tanah dan Lingkungan. Jakarta: Direktorat Jenderal Pendidikan Tinggi. Departemen Pendidikan dan Kebudayaan.

Priyadarshini, R. 1999. "Estimasi modal C (C stock) Masukan bahan organik dan hubungannya dengan jumlah individu cacing tanah pada sistem wanatani". Thesis. Malang: Program Pasca Sarjana UNIBRAW.

Sembel., D, T. 2010. Pengendalian HayatiHama-hama Serangga Tropis dan Gulma. Andi Offset. Yogyakarta.

Setiadi, Y. 1998. Pemanfaatan Mikroorganisme dalam Kehutanan. Departemen Pendidikan dan Kebudayaan Direktorat Jendral Pendidikan Tinggi Pusat Antara Universitas Bioteknologi Bogor IPB. 
Sugiyarto. 2000. Keanekaragaman makrofauna tanah pada berbagai umur tegakan sengon di RPH jatirejo kabupaten kediri. Biodiversitas. Vol 1 No 2 hal 47-53.

Suin., N. M. 1991. Perbandingan Komunitas Hewan Permukaan Tanah antara Ladang dan Hutan di Bukit Pinang, Pinang, Padang. Universitas Andalas, Padang.

Suin., N. M. 2003. Ekologi Hewan Tanah. Jakarta: Bumi Aksara.

Wibowo, C., Wardatur Rizkiyah. 2014. Keanekaragaman Makrofauna Tanah Pada Berbagai Tipe Tegakan Di Hutan Pendidikan Gunung Walat, Sukabumi, Jawa Barat. Jurnal Silvikultur Tropika 05 (1 april 2014): 43-48. 